\title{
Introducing waiting times for health care in a labor supply model for sickness absence
}

\author{
DANIELA ANDRÉN ${ }^{1}$ \\ DAVID GRANLUND \\ ${ }^{1}$ Örebro University Business School, Sweden \\ ${ }^{2}$ Department of Economics, Umeå University, Sweden \\ ${ }^{3}$ HUI Research, Sweden
}

\begin{abstract}
This paper introduces waiting times for different health care services in an empirical labor supply model for the duration of sick leave. In the estimations, we use a unique sample that combines information from the Swedish Social Insurance Agency's register database with information about waiting times from questionnaires for 3,653 employees. The results show that including waiting time variables did not induce substantial changes on the impact of traditional labor supply variables, which suggests that the parameter estimates of the traditional variables are relatively robust.
\end{abstract}

JEL Classification: I12; J21; J28

Key words: health care, labor supply, sick leave, waiting list, worker absenteeism

\section{Introduction}

In countries with a generous welfare system, health related work absences incur substantial costs for employers, workers, and public finances. In Sweden, expenditures for sickness and disability covered by sickness insurance increased in the late 1980s, only to decline from more than 7\% of the GDP in 1989 to less than $4 \%$ in 1998. This decrease was due in part to reducing the compensation levels and in part to moving the responsibility for the payment of the first two weeks of the employees' sick leave to their employers. Owing to increased absences due to sickness, expenditures rose in relation to the GDP from 1998 to 2003 and decreased again after 2003. In 2012, expenditures for people with illnesses or disabilities represented approximately 3\% of the GDP (Försäkringskassan, 2013). The sickness insurance's payments depend on a (simple) medical certificate after the first week and periodic reviews thereafter.

During their sick leave, most of the individuals are also receiving or are waiting to receive treatment from the health care system. In Sweden, as in many public health care systems, access to treatment is rationed by waiting lists, 'regardless of the employment status of individuals.. Approximately one-third of the sick-listed individuals in a Swedish representative sample reported a waiting period for medical examinations, treatments or visits to a health care specialist, and among individuals who were sick listed for musculoskeletal diseases and or who needed surgery, $60 \%$ reported a waiting period of eight weeks or longer (Försäkringskassan, 2005).

Breyer and Schultheiss (2003) classify and discuss different forms of rationing of health services.

* Correspondence to: David Granlund, Department of Economics, Umeå University, SE-901 87 Umeå, Sweden, Phone: + 4690 7869940, E-mail: david.granlund@econ.umu.se 
Some previous studies have reported that economic incentives have significant impact on individual work-absence behavior. ${ }^{2}$ As the relative generosity of sick pay (i.e., the replacement rate) increased, there was a clear disincentive effect as the duration of sick leave increased (e.g. Fenn 1981, Butler and Worrall 1985, and Johnson and Ondrich 1990). Other factors that affect sick leave duration include wages, the type and severity of injury, the physical demands of the job, the willingness of employers to help workers return to work, and the unemployment rate. ${ }^{3}$

To our knowledge, none of the economic studies analyzing the duration of sick leave incorporates waiting times for health care in the model. However, not incorporating this may result in biased estimators for traditional variables such as potential income and costs associated with absence as the literature on socioeconomic inequality in health care utilization includes strong evidence that people with low socioeconomic status consume less health care relative to their needs compared to people with higher socioeconomic status. Several studies have documented this finding using Swedish data. For example, Gerdtham (1997) found a positive income effect on the probability of visiting a physician but not on the frequency of physician visits, while Van Doorslaer et al. (2006) not only confirmed the result for the probability of at least one physician visit during a year but also found an income effect on the average number of physician visits. Similarly, Gerdtham and Sundberg (1998) and Burström (2002), among else, found that lower income groups in relation to need were less likely to visit doctors. Whitehead et al. (1997) found that when controlling for need, manual workers were less likely than professionals to visit a physician, while Löfvendahl et al. (2005) found that the only socioeconomic factor with a significant impact on waiting time for orthopedic surgery was employment. That people with low socioeconomic status consume less health care relative to their needs is also documented in many other developed countries (e.g., Van Doorslaer and Masseri, 2004; Van Doorslaer et al., 2000, 2004).

The goal of the present paper is to study how controlling for waiting times affects the estimates for traditional labor supply variables on duration of sick leave. Using a unique dataset, which supplements the 2002 sample of the RFV-LS register database on sickness absenteeism with information from questionnaires about waiting times, the results show that the estimates of traditional economic and demographic variables of a labor supply model (i.e., cost of being absent, potential income, work hours, age, gender, and marital status) did not change substantially when the model specification was expanded with the waiting time variables.

The remainder of this paper is arranged into six sections. Section 2 presents some institutional settings of sick leave and health care in Sweden. Section 3 discusses the theoretical framework, which is intended to facilitate the discussion of the results. Data and the empirical strategy are presented in Sections 4 and 5. Section 6 contains the results, and Section 7 concludes the paper.

\footnotetext{
See, e.g., Allen (1981), Dunn and Youngblood (1986), Chaudhury and Ng (1992), Dalton and Mesch (1992), Drago and Wooden (1992), Barmby et al. (1991, 1995), Brown and Sessions (1996), Cassel et al. (1996), Johansson and Palme (1996, 2002, 2004), Johansson and Brännäs (1998), Gilleskie (1998), Brown (1999), and Ayyagari, Grossman and Sloan (2011).

See, e.g., Marklund (1995), Hammarström (1996), Selander et al. (1996a, 1996b), and Marklund and Lidwall (1997), Lidwall and Skogman Thoursie (2000), Larsson (2004), and Arai and Skogman Thousie (2004).

${ }^{4}$ Granlund (2010) discussed that shorter waiting time could be one channel through which increased health care expenditures could reduce absence from work due to sickness or disability, but found no statistically significant effect of public health care expenditure on municipality-level absence.
} 


\section{Institutional framework}

Health care in Sweden is nearly exclusively publicly provided. In 2002, private expenditures accounted for only $1.6 \%$ of the total non-dental, non-pharmaceutical health care expenditures (Socialstyrelsen, 2006). The main responsibility for health care provision in Sweden rests on 21 directly elected regional authorities, but the central government has some influence over the health care system. Between 1997 and 2005, the central government negotiated an appointment guarantee with regional authorities. The guarantee stated that patients must be offered medical assistance from the primary care provider within one day, either in the form of a visit or a phone consultation, and that they must not wait more than seven days before seeing a doctor. Those in need of specialist treatment must be guaranteed that they will see a specialist within 90 days. If the regional authorities are unable to meet these requirements, the patient has the right to, at the cost of the authority, seek health care elsewhere, including from a private health care provider contracted by a regional authority (Proposition 1997/98:189).

The appointment guarantee does not establish any time limits regarding actual treatment (Nordgren, 2006), but the Care Guarantee (Vårdgarantin), introduced in 2005, states that patients should not need to wait more than 90 days for treatment after being diagnosed (Anell et al., 2012). Since 2009, Sweden's effort to shorten its queues has been helped by economic incentives, for example, with the Waiting List Billion (Kömiljarden).

\section{Theoretical framework}

Theoretical labor supply models have demonstrated that the demand for absence is likely decreasing with respect to the cost of absence but that it is increasing in the number of scheduled working hours and in non-labor income (Allen, 1981; Brown and Sessions, 1996; Johansson and Brännäs, 1998).

The cost for absence $(c)$ can be increased by a higher wage or lower replacement level, and reduce the demand for absence by making it more expensive. A higher cost of absence can also have an income effect on absence as a higher cost reduces the income for those who are absent. The intuition as to why the number of scheduled working hours $(l)$ should increase the demand for absence is that it increases the marginal utility of leisure.

Income from other source than one's labor increases the demand for absence by reducing the marginal utility of consumption, and thus making the cost of absence less important. If leisure and consumption are complements, a higher non-labor income will also increase the demand for absence by increasing the marginal utility of leisure. The same result holds for potential income $(\mu)$, which in this paper is defined as the income the individuals would have if they were not absent from work due to sickness. As the substitution effect associated with the wage is captured by $c$, it is unambiguous that the causal effect of $\mu$ on the demand for absence is positive.

Previous theoretical models of absence have also stated that personal and job characteristics can affect absence. In such models, it is straightforward to show that sickness increases the demand for absence if it increases the marginal disutility of work. ${ }^{6}$ This is quite reasonable and the idea that sickness increases the marginal disutility of work

\footnotetext{
5 The mathematical derivations of the results of this section are presented in the working paper version of this paper (Andrén and Granlund, 2010).

${ }^{6}$ Viscusi and Evans (1990) and Gilleskie (1998) report evidence that the marginal utility of consumption decreases with sickness. If, on the contrary, marginal utility of consumption would increase with sickness, bad health would have inconclusive effects on the demand for absence as bad health would then increase people's appreciation of both consumption (which they afford more of if the work) and sickness absence.
} 
is a main reason why sickness insurances exist. Thus, if prolonged waiting times prolong the recovery period, it follows that the causal effect of waiting time on the demand for absence is positive.

\section{Data}

The sample analyzed comes from the RFV-HALS data, which have two components: the Swedish Social Insurance Agency (SSIA) register (RFV-LS database) and a large survey conducted by Statistics Sweden (SCB) in collaboration with the SSIA, which includes several questions about how long employees on sick leave have to wait for various health care interventions.

The SCB-SSIA survey was sent to a random sample of 10,799 persons aged 20 to 64 years who started a spell of sick leave lasting at least 15 days between 14 and 27 January 2002. The questionnaire was sent out in April and May 2002, and 6,171 persons answered. Given the focus of this paper, we analyzed only the employed respondents (5,087 persons). Moreover, we analyzed only those employees who answered all questions that could be important according to the theoretical framework, thereby reducing the sample analyzed in this paper to 3,653 observations. Table A1 in the Appendix presents descriptive statistics for the variables used in the empirical analysis, for the whole sample, and based on whether they waited for health care or not. In this section, we discuss the dependent variable as well as $\mu, c$ and the waiting time variables, while the other variables are briefly described in the next section.

The dependent variable in this study is the potentially censored duration of sick leave spells (that started between 14 and 27 January 2002), measured in days, and the status of each spell on 12 February 2003. Approximately $18 \%$ of all analyzed spells are censored, which indicates a relatively high number of cases that lasted longer than one year. The average (censored) duration of sick leave is 129.20 days, while the median is 58 days. $\mu$ is defined as the benefit-qualifying income (SGI) expressed in SEK 10,000 per month, which is used by the Swedish Social Insurance Agency to calculate sickness allowance. The variable is intended to equal the labor income that individuals would have if they were not absent from work due to sickness. It is a good proxy of the potential labor income, but it does not include non-labor income. Weekly cost of being absent $(c)$ is expressed in thousands of SEK and is calculated as

$$
c=10 * 12 / 52 *\left[(1-\delta) \mu+D^{*}(\mu-23.6875)\right]
$$

where 23.6875 is the ceiling of sickness insurance in SEK 10,000, over which no compensation is given, and $D$ is a dummy variable equal to one if $\mu>23.6875$, and zero otherwise. The multiplication by 10 is explained by the fact that we want to express $c$ in SEK 1000 but SGI in SEK 10,000. $\delta$ is the share of the wage the worker receives when absent and equals $80 \%$ from the social insurance plus an additional $10 \%$ guaranteed through collective agreements for nearly all employees between the $15^{\text {th }}$ and $90^{\text {th }}$ day of absence. Municipal and county employees, as well as blue-collar workers and low-income workers who are privately employed, receive an extra $10 \%$ up to their $365^{\text {th }}$ day of absence. ${ }^{7}$ That the compensation levels change means that some employees have different values for the cost of absence, $c$. To address this, we split the data on the $90^{\text {th }}$ and $365^{\text {th }}$ day of absence, so we can obtain multiple observations for those with long sick leave durations. $c$ is the only variable that can differ across observations for an individual.

\footnotetext{
Blue collar workers are defined as those with jobs that do not require university education.
} 
The waiting time dummy variables describe the waiting time (intervals) experienced during the analyzed sick leave for five categories: primary care or a general practitioner (GP), technical investigation, specialists, surgery, and other interventions. For each category, the respondents indicated whether they waited one week or less, two to three weeks, four to seven weeks, eight weeks or more, or they did not need the health service in question. Waiting one week or less is used as a comparison group in the empirical analysis. Table A1 shows that two-thirds of the sample was in need of primary care, while only $15 \%$ required surgery. The proportions of respondents who waited two weeks or more for the different types of health care ranged from $11 \%$ for surgery to $26 \%$ for specialists. Only 5\% waited more than four weeks for primary care, while the proportion for specialists was $17 \%$. The data also show that $18 \%$ of the respondents did not require any health care, $26 \%$ required only one type of health care service and that most of the respondents required two or more types of health care services. ${ }^{8}$

\section{Empirical specifications}

Cox's proportional hazards model (1972) is used to estimate the conditional probability of returning to work in a given period. The theoretical framework suggests that the demand for sick leave, and implicitly sick leave durations, should depend on the cost of absence, the potential income, the number of scheduled working hours, the personal and job characteristics, and the health related variables including waiting times. We include variables that measure, or at least serve as proxies for, these factors. We also include dummy variables for regional social insurance offices, which are expected to reveal the existence of regional general guidelines of sick listing and the different norms regarding sick leave in the various regions.

Our starting point is the traditional labor supply specification that includes the economic variables, $c, \mu$ and $l$ (Table 1a). We then proceed in specifications 2 and 3 by adding groups of demographic (2), health-related, regional and work-related (3) variables used in previous studies and/or expected to affect the duration of sick leave. Finally, in specification 4, we include the waiting time dummies. The purpose is to study whether (and how) these variables affect the estimates of the traditional labor supply variables. Note that this estimation strategy implies that the estimates for the waiting time variables will capture the total impact of these variables, i.e., both the impact of waiting for health care and the impact of having waited for health care.

To account for the number of scheduled working hours, $l$, we include both the normal number of scheduled working hours before the start of the sick leave absence, $w h$, and Worked more than contracted hours, which is a dummy variable taking the value one for employees who worked overtime before the start of their sick leave absence, and zero otherwise. We also include an interaction term between $c$ and wh to test whether the impact of cost of absence on the duration of absence depends on the normal number of scheduled working hours.

The demographic variables included are Women, Age, Widowed, and Divorced. We tested to include polynomials for age and economic variables as well as interactions between Age and Women, but these variables had no statistically significant parameters and are therefore excluded. The work-related variables include indicators on whether the employer is a private company, a municipality, a regional government, the central

\footnotetext{
${ }^{8}$ The full distribution of how many types of health services the respondents waited for are as follows: $17.55 \%$ waited for zero services, $26.09 \%$ waited for one service, $25.49 \%$ waited for two services, $17.36 \%$ waited for three services, $9.77 \%$ waited for four services, and $3.75 \%$ waited for all five types of health services.
} 
government, or another public authority of another type where a private company is used as a control group. We also include indicator variables for the formal training required for the job.

The sickness-related variables included are the number of spells compensated by the sickness insurance only in 2001, regardless their duration; the number of completed spells with different durations during 1996-2001; dummy variables for the diagnosis groups for which the worker was sick listed; and a dummy variable for the type of physician who sick listed the worker. The premise is that these should serve as proxies for health shocks experienced by the workers and thus account for some of the variations in health that are not caused by different waiting times. That these variables do not capture all variation in health implies that estimates for other variables may also capture some effects of health on the duration of sickness absence. Therefore, our reported estimates should not be interpreted as causal effects. Controlling for these health related variables should, however, reduce the omitted variable biased caused by health being correlated with, for example, the economic incentive variables.

\section{Results}

The results from the Cox regression models are shown in Tables 1a-1c. Table 1a presents a summary of specifications 1-4, reporting the estimates for only the traditional economic and demographic variables of the labor supply model. Table $1 \mathrm{~b}$ presents the estimates for the health variables (sickness history and diagnosis), and Table 1c presents the estimates for the waiting time variables. The other results are available from the authors upon request. The results are presented as hazard ratios (i.e., relative risk estimates), where a value above one indicates a positive impact on recovery, i.e., shorter spells.

In the first two specifications, $c$ and $c^{*} w h$ are significant at the $10 \%$ level. Together, the estimates for $c$ and the interaction variable $c^{*} w h$ suggest that an increase in the cost for absence reduces the absence spells for all but the 6 to $7 \%$ of the workers with more than 42 to 43 weekly contracted hours. Unlike Johansson and Brännäs (1998) and Johansson and Palme (2002), who used similar economic variables, we did not find stronger impacts of $c$, which may be because the only source of variation in $c$ in our sample is variation in labor income. ${ }^{10}$ As in Johansson and Brännäs (1998) and Johansson and Palme (2002), our estimates for $\mu$ are not statistically significant. The estimates for Worked more than contracted hours in specifications 1-3 indicate that those working overtime had 11 to $16 \%$ longer spells of sick leave than others. The impact of this variable is, however, reduced by approximately one-third (roughly one standard error) when the waiting time variables are added. Upon closer examination of how the estimates changed

\footnotetext{
The first skill level comprises jobs requiring only primary education, such as cleaners, factory workers, and school meal assistants. The second skill level represents jobs requiring secondary education, e.g., assistant nurses, cashiers, and shop assistants. The third skill level represents jobs that require a three-year university education, e.g., nurses, technicians, and administrative officers. The fourth skill level comprises jobs requiring four years or more of university education and an academic degree, e.g., psychologist, personnel manager, and teacher in secondary education. The occupational titles were classified into broadly similar categories to ensure that the case group and the control group were comparable. The Swedish National Standard for Classification of Skill Levels (SSYK 1996) was used for this purpose (SCB, http://www.scb.se/Pages/List_259304.aspx). This national system is based on an international classification system, ISCO-88, and introduces the concept of skill, defined as the degree of complexity of constituent tasks and skill specialization. 10

Johansson and Brännäs (1998) and Johansson and Palme (2002) used samples in which the share of the wage workers received when absent also varied.
} 
Table 1a: Hazard ratio estimates: economic and demographic parameters

\begin{tabular}{|c|c|c|c|c|}
\hline & (1) & (2) & (3) & (4) \\
\hline Weekly cost of being absent (c) in SEK 1000 & $1.209^{*}$ & $1.180^{*}$ & 1.147 & 1.158 \\
\hline$c^{*}$ wh & $0.996^{*}$ & $0.996^{*}$ & 0.997 & 0.996 \\
\hline$\mu$ in SEK 10,000 per month & 0.993 & 1.023 & 1.001 & 0.988 \\
\hline Weekly contracted hours (wh) in 10 hours & 1.025 & 1.005 & 1.009 & 1.018 \\
\hline Worked more than contracted hours $(=1$; otherwise $=0)$ & $0.889^{* * *}$ & $0.843^{* * *}$ & $0.878^{* * *}$ & $0.920^{*}$ \\
\hline Woman (CG: Man) & & 0.987 & 1.029 & 0.971 \\
\hline Age & & $0.987^{* * *}$ & $0.990^{* * *}$ & $0.990^{* * *}$ \\
\hline Widowed & & $1.438^{* * *}$ & $1.515^{* * *}$ & $1.405^{* *}$ \\
\hline Divorced & & 1.009 & 1.043 & 1.052 \\
\hline Sickness (history; diagnosis; physician) ${ }^{\text {a) }}$ & & & YES & YES \\
\hline Regional social insurance offices & & & YES & YES \\
\hline Work (sector; educational requirement) $^{\text {a) }}$ & & & YES & YES \\
\hline Waiting list dummies ${ }^{\text {b) }}$ & & & & YES \\
\hline LR chi2 $(\mathrm{g})$ & $11.6^{* *}$ & $80.3^{* * *}$ & $898.4^{* * *}$ & $1247.4^{* * *}$ \\
\hline G & 5 & 9 & 58 & 78 \\
\hline Pseudolikelihood & -22843 & -22812 & -22548 & -22342 \\
\hline
\end{tabular}

Notes: CG stands for comparison group. Hazard ratio $>1$ means a higher risk for longer absence. The estimate is significant at the $10 \%$ level $(*)$, at the $5 \%$ level $(* *)$, and at the $1 \%$ level $(* * *)$. These notes hold for all tables of estimates. The estimated parameters for ${ }^{\mathrm{a}}$-variables are reported in Table $1 \mathrm{~b}$ and for ${ }^{\mathrm{b})}$-variables are reported in Table $1 \mathrm{c}$.

when waiting time variables were added, i.e., comparing specifications 3 and 4, we see that all changes are small and not statistically significantly different from zero using an informal Wald test where the covariance across specifications is assumed to be zero. The same result is obtained when comparing specifications 4 and 2. Even if we take the estimates of specification 2 and 3 as given (i.e., as estimated without error) and test whether the estimates of specification 4 differ from them, we find no statistically significant differences for the economic and demographic variables when comparing with specification 3 and only for Worked more than contracted hours at the 5\% level and for Age at the 10\% level when comparing with specification 2. Table 1a shows that the change in the estimate for Age occur when the sickness, regional and work variables are added. According to specification 2, an increase in age with 10 years increases the duration of sick leave with $1.3 \%$, while the corresponding estimate for both specifications 3 and 4 is $1.0 \%$. The change in the estimate for Worked more than contracted hours are slightly larger. Those that had worked overtime had 16\% longer spells according to specification 2 , but only $12 \%$ and $8 \%$ longer spells according to specification 3 and 4 , respectively.

That we only find small and insignificant effects on the economic variables when waiting time variables were added is surprising as previous studies have found clear relationships between socioeconomic variables such as income and utilization of health care. Therefore, we expected that controlling for waiting time variables would affect the estimate for, e.g., potential income, but columns 3 and 4 of Table 1a show that this is not the case. 
Table 1b: Hazard ratio estimates: sickness and job parameters

\begin{tabular}{|c|c|c|}
\hline & (3) & (4) \\
\hline Economic incentives & YES & YES \\
\hline Demographics & YES & YES \\
\hline Regional SI offices dummies & YES & YES \\
\hline Waiting list dummies & & YES \\
\hline Number of compensated spells during 2001 & $0.931^{* * *}$ & $0.944^{* * *}$ \\
\hline \multicolumn{3}{|c|}{ Number of completed spells $1996-2001$ by duration } \\
\hline 1-14 days & $1.038^{* *}$ & $1.063^{* * *}$ \\
\hline $15-28$ days & 1.004 & 1.040 \\
\hline 29-59 days & $0.941^{*}$ & 0.956 \\
\hline $60-89$ days & 0.998 & 0.983 \\
\hline 90-179 days & $0.856^{* * *}$ & $0.874^{* * *}$ \\
\hline 180-364 days & $0.793^{* * *}$ & $0.805^{* * *}$ \\
\hline $1-2$ years & 1.004 & 1.042 \\
\hline $2-3$ years & 1.174 & 1.246 \\
\hline $3-4$ years & $1.949^{* *}$ & 1.298 \\
\hline 4-6 years & $2.765^{* * *}$ & $2.858^{* * *}$ \\
\hline \multicolumn{3}{|l|}{ Diagnosis (CG: Injuries and poisoning) } \\
\hline Mental disorder & $0.603^{* * *}$ & $0.552^{* * *}$ \\
\hline Circulatory system & $0.659^{* * *}$ & $0.648^{* * *}$ \\
\hline Respiratory system & $2.426^{* * *}$ & $2.278^{* * *}$ \\
\hline Musculoskeletal & $0.782^{* * *}$ & $0.833^{* * *}$ \\
\hline Other & 0.945 & $0.873^{* *}$ \\
\hline
\end{tabular}

Physician (CG: Primary care)

$\begin{array}{rll}\text { Company } & 0.681^{* * *} & 0.675^{* * *} \\ \text { Private } & 0.850^{* * *} & 0.823^{* * *} \\ \text { Specialist } & 0.990 & 1.016 \\ \text { Not specified } & 1.435 & 1.346\end{array}$

Employer (CG: Private)

$\begin{array}{rll}\text { Municipality } & 0.886^{* *} & 0.907^{* *} \\ \text { Regional } & 1.002 & 0.994 \\ \text { State } & 1.065 & 1.073 \\ \text { public authority } & 0.745^{*} & 0.762^{*} \\ \text { Other employer } & 0.921 & 0.930\end{array}$

Educational requirement (CG: Occupation with very low or no requirements)

$\begin{array}{rll}\text { High school } & 1.167^{*} & 1.161^{*} \\ \text { High school }+ & 1.260^{* *} & 1.260^{* *} \\ \text { Cllege/university } & 1.186^{*} & 1.177^{*} \\ \text { ship occupation } & 0.976 & 0.928\end{array}$


Table 1c: Hazard ratio estimates: waiting times parameters

\begin{tabular}{|c|c|}
\hline & (4) \\
\hline Economic incentives & YES \\
\hline Demographics & YES \\
\hline Sickness (history; diagnosis; physician) & YES \\
\hline Regional social insurance offices & YES \\
\hline Work (sector; educational requirement) & YES \\
\hline \multicolumn{2}{|l|}{ Waiting for primary care or a GP (CG: 1 week or less) } \\
\hline 2-3 weeks & $0.738^{* * *}$ \\
\hline 4-7 weeks & $0.771^{* * *}$ \\
\hline 8 weeks or more & 0.773 \\
\hline Not needed & 1.013 \\
\hline
\end{tabular}

Waiting for a technical investigation (CG: 1 week or less)

$\begin{aligned} \text { 2-3 weeks } & 0.714^{* * *} \\ \text { 4-7 weeks } & 0.761^{* * *} \\ \text { 8 weeks or more } & 0.713^{* * *} \\ \text { Not needed } & 1.099\end{aligned}$

Waiting for a specialist (CG: 1 week or less)

$\begin{aligned} \text { 2-3 weeks } & 0.897 \\ \text { 4-7 weeks } & 0.816^{* *} \\ 8 \text { weeks or more } & 0.804^{* *} \\ \text { Not needed } & 1.321^{* * *}\end{aligned}$

Waiting for a surgery (CG:1 week or less)

$\begin{aligned} \text { 2-3 weeks } & 0.787 \\ 4-7 \text { weeks } & 1.423^{* *} \\ 8 \text { weeks or more } & 1.277^{* *} \\ \text { Not needed } & 1.051\end{aligned}$

Waiting for another type of intervention (CG: 1 week or less)

\begin{aligned} & 2-3 weeks 0.880 \\ & 4-7 weeks 0.944 \\ & 8 weeks or more $0.819^{*} \\ &$ Not needed $1.272^{* * *} \\ &$\hline\end{aligned}


Table $1 \mathrm{~b}$ shows, among other things, that workers sick listed due to mental disorders have the longest sick leave durations, all else being equal, and that controlling for waiting times has negligible effects on the estimates for the employer and educational indicators.

The point estimates in Table 1c indicate that for most categories of health care, waiting 2 to 3, 4 to 7, or eight weeks or more, has positive impacts on the duration of sick leave compared to waiting one week or less. In all specifications, the impacts related to primary care are significant at the 5\% level, except for the few that waited eight weeks or more. Furthermore, the impacts for technical investigations and most of the impacts for specialist are significant.

For surgery, the results indicate that people waiting more than four weeks actually have significantly shorter spells than others. Because of the descriptive estimation strategy, the results should not be interpreted as indicating that waiting for surgery is advantageous. Instead, one interpretation is that waiting time is used to a greater extent in surgery than in other health care services as a means of prioritizing. The impact of waiting for another type of intervention is small and not significant at the 5\% level.

\section{Conclusions}

Using a unique sample that contains register and survey data for 3,653 Swedish employees, we found that controlling for waiting times had only small and statistically insignificant effects on the estimates for the traditional labor supply variables. This indicates that there is no large income-related inequality in waiting times. This result was unexpected in light of previous research that has found evidence of socioeconomic inequality in the utilization of health care. However, as our study is restricted to employees, the result is consistent with Löfvendahl et al. (2005), who found that the only socio-economic factor with a significant impact on waiting time for orthopedic surgery was employment. An interesting topic for future research would be to study the associations between waiting times, socioeconomic status and sickness absence using data from a period after the implementation of the Care Guarantee and the Waiting List Billion. Comparing results from such a study with our results would inform about the consequences of these reforms. If the data required for such research becomes available, it would also be interesting to study the whether waiting times for return visit have increased due to the Waiting List Billion queues and, if so, the effect of this on sickness absence.

\section{Acknowledgements}

We wish to thank Fredrik Norström and seminar participants at Växjö University, Örebro University, the 30th and the 32nd Nordic Health Economists Study Group Meeting, the 26th Meeting of the European Economic Association, and the 2nd conference of the Swedish Health Economics Association for helpful comments and suggestions. We are also grateful to the Swedish Council for Working Life and Social Research (FAS) for financial support. 


\section{References}

Allen, S.G. (1981). An Empirical Model of Work Attendance. Review of Economics and Statistics, 63(1), 77-87.

Andrén, D. \& Granlund, D. (2010) "Waiting for the other shoe to drop": waiting for health care and duration of the sickness leave. Umeå Economic Studies, 814.

Anell A, Glenngård AH, Merkur S. Sweden: Health system review. Health Systems in Transition, 2012, 14(5):1-159.

Arai, M. \& Skogman Thoursie, P. (2004). Sickness Absence: Person and Establishment effects. Swedish Economic Policy Review, 11(1). 9-28.

Ayyagari, P., Grossman, D. \& Sloan, F. (2011) Education and health: evidence on adults with diabetes. International Journal of Health Care Finance and Economics, 11(1), 35-54.

Barmby, T.A., Orme, C.D. \& Treble, J.G. (1991). Worker Absenteeism: An Analysis Using Microdata. Economic Journal, 101(405), 214-229.

Barmby, T.A., Orme, C.D. \& Treble, J.G. (1995). Worker Absence Histories: A Panel Data Study. Labour Economics, 2(1), 53-65.

Breyer, F. \& Schultheiss, C. (2003) "Primary" Rationing of Health Services in Ageing SocietiesA Normative Analysis. International Journal of Health Care Finance and Economics, 2(4), 247-264.

Brown, S. \& Sessions, J. G. (1996). The economics of absence: theory and evidence. Journal of Economic Surveys, 10(1), 23-53.

Brown, S. (1999). Worker absenteeism and overtime bans. Applied Economics, 31(2), 165-174.

Burström, B. (2002). Increasing inequalities in health care utilization across income groups in Sweden during the 1990s? Health Policy, 62(2), 117-129.

Butler, R. J. \& Worrall, J. D. (1985). Work injury compensation and the duration of nonwork spells. Economic journal, 95(379), 580-589.

Cassel, C., Johansson, P. \& Palme, M. (1996). A dynamic discrete choice model of blue collar worker absenteeism in Sweden 1991. Umeå Economic Studies, 425, Umeå University.

Chaudhury, M. \& Ng, I. (1992). Absenteeism Predictors: Least Squares, Rank Regression, and Model Selection Results. The Canadian Journal of Economics, 25(3), 615-635.

Cox, D.R. (1972). Regression models and life tables. Journal of the Royal Statistical Society, Series B 34, 187-220.

Dalton, D.R., \& Mesch, D.J. (1992). The impact of employee-initiated transfer on absenteeism: a four-year cohort assessment. Human Relations, 45(3), 291-304.

Drago, R., \& Wooden, M. (1992). The determinants of labor absence: economic factors and work group norms. Industrial and Labor Relations Review, 45(4), 34-47.

Dunn, L.F., \& Youngblood, S.A. (1986). Absenteeism as a mechanism for approaching an optimal labour market equilibrium: an empirical study. Review of Economics and Statistics, 68(4), 668-74.

Fenn, P.T. (1981). Sickness duration, residual disability, and income replacement: an empirical analysis. Economic Journal, 91(361), 158-173. 
Försäkringskassan [Swedish Social Insurance Agency] (2005), Sjukskriven i onödan?

[Unnecessarily sick listed?] Analyserar, 2005:5.

Försäkringskassan [Swedish Social Insurance Agency] (2013), Social Insurance in Figures 2013.

Gerdtham, U.-G. (1997). Equity in health care utilization: further tests based on hurdle models and Swedish micro data. Health Economics, 6(3), 303-319.

Gerdtham, U.-G. \& Sundberg, G. (1998). Equity in the delivery of health care in Sweden. Scandinavian Journal of Social Medicine, 26(4), 259-263.

Gilleskie, D. (1998). A dynamic stochastic model of medical care use and work absence. Econometrica, 66(1), 1-45.

Granlund, D. (2010). The effect of health care expenditure on sickness absence. The European Journal of Health Economics, 11(6), 555-568.

Hammarström, A. (1996). Ungdomsarbetslöshet och ohälsa [Youth unemployment and bad health]. Studentlitteratur, Lund.

Johansson, P., \& Brännäs, K. (1998). A household model for work absence, Applied Economics, 30(11), 1493-1503.

Johansson, P., \& Palme, M. (1996). Do economic incentives affect worker absence? Empirical Evidence Using Swedish Data. Journal of Public Economics, 59(2), 195-218.

Johansson P., \& Palme, M. (2002). Assessing the Effects of Public Policy on Worker Absenteeism. Journal of Human Resources, 37(2), 381-409.

Johansson P., \& Palme, M. (2004). Moral Hazard and Sickness Insurance: Empirical Evidence from a Sickness Insurance Reform in Sweden, IFAU working paper 2004:10.

Larsson, L. (2004). Harmonizing unemployment and sickness insurance: Why (not)? Swedish Economic Policy Review, 11, 151-188.

Lidwall, U., \& Skogman Thoursie, P. (2000). Sjukfrånvaro och förtidspension: en beskrivning och analys av utvecklingen under de senaste decennierna [Sickness absence and disability pension in Sweden during the last decades]. RFV Analyserar 2002:2.

Löfvendahl, S., Eckerlund, I., Hansagi, H., Malmqvist, B., Resch, S., and Hanning, M. (2005). Waiting for orthopaedic surgery: factors associated with waiting times and patients' opinion. International Journal for Quality in Health Care Advance Access, Int J Qual Health Care 17: 133-140.

Marklund, S. (1995). Vilka blir långtidssjuka? [Who are the long-term sick?] In Rehabilitering i ett samhällsperspektiv [Rehabilitation from a social perspective], ed. S. Marklund, Studentlitteratur, Lund.

Marklund, S., \& Lidwall, U. (1997). Vilka blir långtidssjukskrivna? [Who are the long-term sick?] In Risk- och friskfaktorer -sjukskrivning och rehabilitering i Sverige, (Sickness absenteeism and vocational rehabilitation in Sweden), ed. S. Marklund, RFV Redovisar 1997:6.

Nordgren, L. (2006). Intåget av valfrihet och vårdgaranti i den svenska sjukvården - en diskursanalys [The arrival of freedom of choice and care guarantee in the Swedish healthcare a discourse analysis]. Kommunal Ekonomi och Politik 10(1), 37-59 (in Swedish).

Proposition 1997/98:189 Patientens ställning [The patient's position] Regeringen: Stockholm.

Selander, J., Marnetoft, S-U., Bergroth, A., Ekholm J. (1996a). Arbetslösa sjukskrivna - en jämförande studie av arbetslösa sjukskrivna och anställda sjukskrivna i Stockholm 
[Unemployed and on sick leave - a comparative study of sick leave among unemployed and employed in Stockholm]. Mitthögskolan i Östersund, Rapport 1996:6.

Selander, J., Marnetoft, S-U., Bergroth, A., Ekholm J. (1996b). Arbetslösa sjukskrivna - en jämförande studie av arbetslösa sjukskrivna och anställda sjukskrivna i Jämtlands glesbygd [Unemployed and on sick leave - a comparative study of sick leave among unemployed and employed in rural Jämtland]. Centrum för socialförsäkringsforskning, Mitthögskolan i Östersund, Rapport 1996:7.

Socialstyrelsen [National Board on Health and Welfare] (2006). Statistik över kostnader för hälsooch sjukvården 2005 [Health care costs statistics 2005]. Socialstyrelsen: Stockholm.

Van Doorslaer, E., Koolman, X. \& Jones, A. (2004). Explaining income-related inequalities in doctor utalisation in Europe. Health Economist, 13(7), 629-647.

Van Doorslaer, E. \& Masseria, C. (2004). Income related inequality in the use of medical care in 21 OECD countries. Chapter 3 in Towards High-Performing Health Systems Policy Studies, OECD.

Van Doorslaer, E., Masseria, C. \& Koolman, X. (2006). Inequalities in access to medical care by income in developed countries. Canadian Medical Association Journal, 174(2), 187-188.

Van Doorslaer, E., Wagstaff, A., Van Der Burg, H., Christiansen, T., Graeve, D.D., Duchesne, I., Gerdtham, U.-G., Gerfin, M., Geurts, J., Gross, L., Häkkinen, U., John, J., Klavus, J., Leu, R., Nolan, B., O'Donnell, O., Propper, C., Puffer, F., Schellhorn, M., Sundberg, G., and Winkelhake, O. (2000). Equity in the delivery of health care in Europe and the US. Journal of Health Economics, 19(5), 553-583.

Viscusi, W.K. \& Evans, W.N. (1990). Utility functions that depend on health status: Estimates and economic implications. The American Economic Review, 80(3), 353-374.

Whitehead, M., Evandrou, M., Haglund, B., Diderichsen, F. (1997). As the health divide widens in Sweden and Britain, what's happening to access to care? British Medical Journal, 315(7114),1006-1009.

(C) 2015 the author(s). This article is an open access article distributed under the terms and conditions of the Creative Commons Attribution license (http://creativecommons.org/licenses/by/4.0/). 